\title{
Biogeosystem engineering is the basis for the practice of eco-oriented diversification of water supply enterprises
}

\author{
Aleksandr Skryabin ${ }^{1, *}$ \\ ${ }^{1}$ Don State Technical University, 344003, Gagarin Square, 1, Rostov-on-Don, Russia
}

\begin{abstract}
In the article, in relation to the water supply sector, a biogeosystem technical approach is considered as integration of innovative water treatment technologies into the natural environment, based on preventive measures to affect the water environment, approaches, methods, technical solutions and technologies that do not reflect natural processes. The article considers theoretical and methodological issues of eco-oriented diversification of water supply enterprises based on a biogeosystem technical approach, environmental and economic efficiency of this diversification, taking into account environmental factors. A comparative analysis of the options for biocidal technologies used for drinking water disinfection is presented. It is demonstrated that the biogeosystem technical approach provides an increase in the socio-ecological and economic efficiency of technological activity in different natural environments.
\end{abstract}

\section{Introduction}

It is generally accepted that the industrial technological paradigm of social development disrupts the current ecological framework of the biosphere. The biosphere is represented as a "hunting area" for existing natural and technological complexes that do not predict longterm consequences of their activities, both within and outside their life cycle. Further development within this paradigm creates conditions for the restructuring of society based on social Darwinism principles. In this aspect, along with proactive actions (formation of a portfolio of investment projects within the framework of targeted programs, implementation of energy-saving water treatment technologies), development and implementation of eco-oriented technologies for chemical and biocidal water treatment and the study of the drinking water supply market are becoming actual.

The analysis of the existing material on systemic research problems makes it possible to conclude that an enterprise, producing products/services is a complex systemic/naturaltechnological complex. This is due to their specific feature - significant heterogeneity, that is, the presence of both technological components and people (the term "complex" is used), and its consideration as a system (a coherent complex of artificial and natural elements) [1]. They are characterized by the following properties: the presence of significant stable ties,

* Corresponding author: skryabin@zsro.ru 
an integral set of elements, etc. Such systems re studied in the framework of systems engineering.

In practical terms, one of the ways of eco-oriented development of natural and technological complexes at the system level is possible within the framework of biogeosystem engineering [1-2]. The works [1-8] present the main provisions and principles of biogeosystem engineering in the context of soil fertility management and technological processes with negative feedback of the effect on the natural environment. As a research area, biogeosystem engineering studies systemic properties of natural systemtechnological complexes, processes, systemic issues of their creation and improvement to obtain the maximum socio-ecological result [1]. Use of biogeosystem engineering methodology in the field of water supply for industry sector/population requires practical research, presented in this article.

In the context of water supply for the population, the main principles of biogeosystem engineering have been formulated:

- ecodesign in water supply field in the region/regions, including technological processes of municipal, industrial and agricultural water supply in compliance with chemical and biological safety standards and following financial and economic feasibility;

- organization of technological content of society preventive management in terms of water supply environmental safety based on special management procedures in regional and municipal authorities [9-11].

The purpose of biogeosystem engineering in the context of water supply is considered to be the solution of a fundamental problem: first, the synthesis of ecologically safe aquatic environment; second, an environmentally safe drinking water supply based on the management imperative on the forward negative feedback principle.

It should be noted that existing environmental measures remain half-measures within the industrial technological platform, without consideration of possible limiting the aftereffect of technologies that do not correspond to the Sustainable Development vision. That is, ecology and economics are actually "excluded" from technological processes. At this time, negative aftereffects have positive feedback constant over time, reinforcing the negativity. It disrupts the balance of natural and biological processes, their reproduction requires significant costs. In this regard, the biogeosystem technical approach to the nature management practice, including use of water resources, largely allows to overcome the conflict of interests of nature (pursuance of biodiversity) and society (the desire to extract civilization benefits, often to the detriment of nature).

Here, the main method of biogeosystem engineering, the systemic approach, is implemented by specific procedures of technical/technological, environmental and economic analysis. The synthetic results, obtained on this basis, remove the abovementioned conflict of interests. For instance, in terms of environmental safety of water supply to the population, the quality of their life is improving.

Technical/technological means, synthesized within the framework of biogeosystem engineering procedures, ensure a decrease in material and energy costs of society by natural damage reduction. It results from negative feedback implementation.

Within shown aspects, biogeosystem engineering in the field of water supply shall be considered as a certain technological platform, combining research work with requirements of the water market and new available technologies (NAT). As a result, the tasks of both sustainable food production and safe drinking water supply to the population can be solved.

Within the context of the above mentioned, we will formulate main problematic tasks of biogeosystem engineering in terms of water supply:

- identification of general system characteristics and patterns, not depending on specific equipment/technologies in water supply; 
- study of the sequence of operations for transformation and use of water and resulting formation of the selection criteria for NAT;

- development of procedures for implementation and creation of specific equipment/technologies based on principles of biogeosystem engineering

in the form of water supply complexes (enterprises) and their financial and economic justification.

Within the framework of the taken biogeosystem technical approach to water supply, we can identify certain social and economic aspects of access to safe drinking water. It is known, that the level of well-being is reflected by a complex of human needs (values): material/economic (water, food, etc.), socio-cultural (recreation, education, health care, etc.), personal and environmental. The latter are not always measurable in value terms, but they increase the material quality (for example, ecologically safe drinking water) and sociocultural needs (improvement of environmental conditions, public health preservation, etc.) [12-13]. In the above aspects, "water is a water resource" in the consumer view has a consumer value and has the following properties: a condition for public health preservation; a condition for biodiversity preservation; human activity factor, etc. At the same time, achievement of the normative and sanitary quality of fresh (drinking) water results in a number of problems, requiring a systematic solution: technical and technological, economic (investment), social, environmental and regulatory.

Summing up the above, it is evident that provision of population with water of adequate quality is possible under the following conditions:

- natural water for drinking purposes shall be purified from harmful chemical and microbiological components according to requirements of SanPiN 2.1.4.1074-01 for safety; - in distribution networks, secondary bacterial contamination of drinking water shall be excluded;

- fresh water shall be treated as a limited resource. It demands balancing of the limiting technogenic and anthropogenic load on natural environments with their adaptive capacity.

Methodological provisions of eco-oriented diversification shall be based on:

- analysis of ecodesign tasks by ensuring the population's access to environmentally safe drinking water and expanding the market for environmental services by providing the population with safe water;

- equal priority of social, environmental and economic factors, determining social needs;

- use of system analysis methods in the analysis of the relationship between the natural environment and society components, i.e. use of a systematic approach to a comprehensive justification of water supply ecodesign. A comprehensive justification shall meet performance criteria both in cost equivalents and in the format of dimensionless indicators. Socioeconomic assessment of efficiency shall be presented in the format of financial and investment appeal.

It should be noted here that water supply and wastewater treatment sector dominates the global market for environmental services. By 2020-2021, this sector volume is estimated at up to $\$ 1,000 \mathrm{bln}$. [14].

In terms of the above, a special place is occupied by the diversification of water supply enterprises. Thanks to diversified production with a wide range of products, these enterprises are becoming more stable and competitive [15]. But in this case, it is necessary to consider the assessment of environmental factors effect for selection of the best available water purification technologies. Choice efficiency shall be considered within two categories - social (social and environmental results) and commercial (financial and investment results), despite their internal inconsistency.

Some aspects of the practice of water supply diversification are described in [16]. As there is no competitive market for drinking water in Russia, which allows us to talk about municipal water supply profitability, in current economic conditions, efficiency of 
technologies for chemical and biocidal water treatment shall be considered not at the maximum profit, but at the minimum of the reduced cash costs (investment, production, social and environmental). The cash flow itself in relation to investment cycle stages creation and operation - can be represented at separate time intervals of the payment flow in the form of constant or variable differential annuities. Comparative analysis of water treatment options, using classical (liquid chlorine) and hypochlorite technologies as applied to WTS-3 in Novocherkassk ( $\sim 18$ thous. $\mathrm{m}^{3} /$ day) is shown in Table 1 .

Table 1. Reduced costs for the implementation of various methods of water disinfection

\begin{tabular}{|c|c|c|}
\hline Parameters & $\begin{array}{c}\text { Use of } \\
\text { Basic variant } \\
\text { (liquid chlorine) }\end{array}$ & $\begin{array}{c}\text { sodium hypochlorite } \\
\text { at the 1st and 2nd } \\
\text { stages }\end{array}$ \\
\hline Investment costs $\left(K_{0}\right)$, rub. & 66,000 & 360,000 \\
\hline Current costs $(I)$, rub. & 481,125 & 329,075 \\
\hline Reduced costs, rub. & 778,125 & 464,966 \\
$I+\frac{K \cdot(1+r)^{T} \cdot r}{(1+r)^{T}-1}$ & & \\
\hline
\end{tabular}

Comparison of the above methods of water disinfection, considering both economic and environmental results, was performed according to the criterion of equivalent costs, with a discount rate $r=0.1$. Calculation results are presented in Table 2 .

The comparative selection results of the best technology for reduced costs are shown in Tables 3 and 4.

The following technologies were analyzed:

1. Oxidant-disinfectant - imported liquid chlorine.

2. Use of imported grade A sodium hypochlorite as a reagent.

3. Electrolysis sodium hypochlorite reagent produced on consumption site.

Table 2. Equivalent costs of different methods of water disinfection at WTS-3

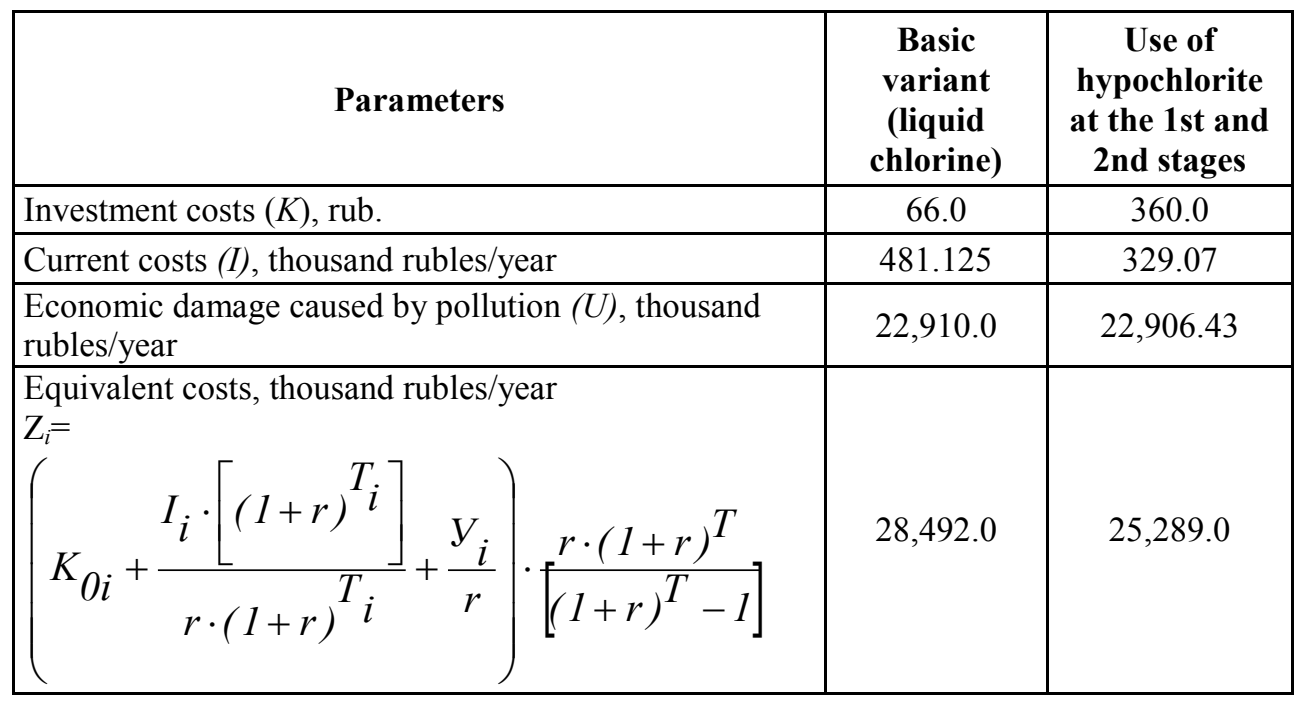

Table 4 shows the comparison results of variants 1-3 and the author's calculation 
specified for individual items.

Table 3. Economic assessment of various variants of chemical-biocidal water treatment

\begin{tabular}{|c|c|c|c|c|}
\hline \multirow[b]{2}{*}{$\begin{array}{c}\text { Expenditure } \\
\text { (thousand rub.) }\end{array}$} & \multicolumn{4}{|c|}{ Variants } \\
\hline & $\begin{array}{c}\text { liquid } \\
\text { chlorine } \\
\text { (imported) }\end{array}$ & $\begin{array}{c}\text { imported } \\
\text { hypochlorit } \\
\text { e } \\
\text { concentrat } \\
\text { e }\end{array}$ & $\begin{array}{l}\text { electrolysis } \\
\text { sodium } \\
\text { hypochlorite at } \\
\text { consumption } \\
\text { site }\end{array}$ & $\begin{array}{c}\text { electrolysis } \\
\text { sodium } \\
\text { hypochlorite at } \\
\text { consumption } \\
\text { site } \\
\text { (with } \\
\text { clarifications) }\end{array}$ \\
\hline Capital investments & - & $1,064.97$ & 1,120 & 1,120 \\
\hline $\begin{array}{l}\text { Operational } \\
\text { costs }\end{array}$ & $4,086.4$ & $5,181.7$ & 977.85 & $2,785.4$ \\
\hline Reduced costs & $4,086.4$ & $6,246.67$ & $2,097.85$ & $3,905.4$ \\
\hline $\begin{array}{l}\text { Use cost }{ }^{*} \text { of } 1 \mathrm{~kg} \\
\text { of active chlorine }\end{array}$ & 136.21 & 208.22 & 69.92 & 130.18 \\
\hline
\end{tabular}

* Biocidal action identity of $1 \mathrm{~kg}$ of $\mathrm{Cl}_{2}$ and $\mathrm{NaClO}$

Table 4. Capital expenditures and revised operating costs for production at consumption site of electrolytic sodium hypochlorite

\begin{tabular}{|c|c|c|c|}
\hline \multirow{2}{*}{ Name of items } & \multirow{2}{*}{$\begin{array}{c}\text { Cost, } \\
\text { thousand rubles }\end{array}$} & \multicolumn{2}{|c|}{$\%$ of expenses } \\
\hline & & of reduced & operational \\
\hline \multicolumn{4}{|c|}{ Capital investments } \\
\hline $\begin{array}{l}\text { Delivery, installation, } \\
\text { commissioning, pumps } \\
\text { and ventilation included }\end{array}$ & 10,200 & - & - \\
\hline $\begin{array}{l}\text { Preparation of buildings for } \\
\text { erection }\end{array}$ & 700 & - & - \\
\hline Design works & 300 & - & - \\
\hline $\begin{array}{l}\text { Total capital investments } \\
(10 \% \text { wear) }\end{array}$ & 11,200 & 28.68 & - \\
\hline \multicolumn{4}{|c|}{ Operational costs } \\
\hline Salt & 178.85 & 4.58 & 6.42 \\
\hline Electricity & 190.35 & 4.87 & 6.83 \\
\hline Heating & 481.5 & 12.33 & 17.29 \\
\hline $\begin{array}{l}\text { Reagents }(\mathrm{HCl} \text { for } \\
\text { electrodes) }\end{array}$ & 35.0 & 0.91 & 1.26 \\
\hline $\begin{array}{l}\text { Gas analyzers, gas masks, } \\
\text { SCBA, } \\
\text { suits }\end{array}$ & 49.7 & 1.27 & 1.78 \\
\hline Salary of nine operators & $1,080.0$ & 27.65 & 38.77 \\
\hline Electrode recoating & 400 & 10.24 & 14.36 \\
\hline Equipment maintenance & 130 & 3.33 & 4.67 \\
\hline Security (2 people) & 240 & 6.14 & 8.62 \\
\hline Total operational costs & $2,785.4$ & - & 100 \\
\hline Total reduced costs & $3,905.4$ & 100 & - \\
\hline
\end{tabular}

Note: it is assumed that there are no costs for water treatment (softening) 
In conclusion, we note that:

1. The above provisions shall serve as the basis for the design consideration of different disinfection methods used in water treatment or purification technologies.

2. Drinking water, meeting safety parameters, is already a dominant factor to reduce social and economic degradation in certain regions and populated areas.

3. All previously presented calculations and analysis of various options for water disinfection were performed for a relatively small production of sodium hypochlorite (30 t/year), and resulting in corresponding productivity of the water supply system for treated water. When switching to large amounts of disinfectant and water volumes, it is possible to adjust the values of certain consumption items.

\section{References}

1. A. P. Moskalenko, Biogeosystem Technique, 1(3), 64-81 (2015)

2. V. P., Soil science, 8, 1010-1022 (2011)

3. Irrigation policy demands a paradigm shift

4. English J. Marshall, Journal of irrigation and drainage engineering, 267-277 (2002)

5. Food and agriculture organization of the united nations (2011)

6. V. P. Kalinitchenko, FAO. Global Forum on Salinization and Climate Change, Topic I. Identifying systems vulnerable to salinization, including agroecosystems (irrigated and rainfed), soils, water bodies, biodiversity and fragile ecosystems and available tools and information systems to assess and monitor the evolution of salinization. Session II (2010)

7. V. P. Kalinitchenko, European researcher, 7(25), 1042-1049 (2012)

8. A. P. Moskalenko, Bulletin of Platov South-Russian State Polytechnic University (NPI), Socio-economic sciences, 4 (2012)

9. D. F. Simonyan, Economics and entrepreneurship, 6(1), 1055-1062 (2015)

10. A. S. Kharasova, Russian entrepreneurship, 20, 16-20 (2014)

11. M. E. Strokin, Actual problems of the humanities and natural sciences, 5, 135-139 (2012)

12. S. A. Moskalenko, Economics and entrepreneurship, 6, 482-487 (2013)

13. S. A. Moskalenko, Economics and entrepreneurship, 6(1), 242-247 (2015)

14. V.A. Sapozhnikova, Water supply and sanitary engineering, 5, 36-42 (2011)

15. N. V. Lyashenko, VINITI No. 350-V2010 dated 08/06/2010 (the abstract is published in the bibliographic index of VINITI "Deposited scientific works"), 8 (2010)

16. A. Yu. Scryabin, Competitiveness in the global world: Economics, Science, Technologies, 6(4), 164-168 (2017) 